\title{
Corporate Social Responsibility in India: A Case Study of Public and Private Sector
}

\author{
Tasneem, R. ${ }^{1}$, Jain, S. $^{2}$ \\ ${ }^{I}$ (Department of Psychology, Jamia Millia Islamia, India) \\ ${ }^{2}$ (Centre for Early Childhood Development \& Research, Jamia Millia Islamia, India)
}

\begin{abstract}
This paper attempts to understand the work done by a public sector and private sector organization in the field of corporate social responsibility(CSR). This study is based on the primary data of Oriental Insurance Company Ltd. (OICL) and secondary data of Reliance Life Insurance Company Ltd. (RLIC). The primary data for Oriental Insurance Company Ltd. was collected through a semi-structured interview and the secondary data for Reliance Life Insurance Company Ltd. was collected through their web portal. The findings suggest that though the corporate social responsibility activities revolve around similar areas for both the sectors, focusing on community, health, education, and infrastructure, yet the policies and procedures regarding corporate social responsibility were structured and systematic for Reliance Life Insurance Company Ltd. in comparison to that of Oriental Insurance Company Ltd. Both public (OICL) and private (RLIC) sector enterprises work with a special set of constraints and challenges, due to which they strategize their operations differently. The focus of organizations should not only be conduction of CSR, but creating sustainable practices should be the focus.
\end{abstract}

Keywords : corporate social responsibility, Oriental Insurance Company Ltd., private sector, public sector, Reliance Life Insurance Company Ltd.

\section{Introduction}

The success of any organization depends on its ability to cater to the needs of people in some way. While the organization uses resources available to it such as human resources, energy and land, it also has the responsibility to give something back to the community it serves. It is this interdependent relationship that guarantees success to both the organization and the community. While the primary goal of an organization is to effectively cater to the needs of the people, it also needs to go beyond and help in the betterment of the community. These practices taken by the organizations are termed as Corporate Social Responsibility (CSR). Corporate Social Responsibility (CSR) is exercised by organizations when they conduct their business in an ethical way, taking account of the social, environmental and economic impact of how they operate, and going beyond compliance. It covers the relationship between corporations and the societies with which they interact. CSR defines society in the widest sense, and on many levels, to include all stakeholder and constituent groups that maintain an ongoing interest in the organization's operations. It is defined by McWilliams et al (2006) in Armstrong $^{1}$ (1996) as actions taken by businesses that further some social good beyond the interests of the firm and that which is required by law. It has also been described as "the impact of business on behavior". Corporate social responsibility is also referred to as "pro-social corporate endeavors and has been traditionally conceptualized as the obligation of the managerial authority to take action to protect and improve both the welfare and the interest of the organizations" ${ }^{2}$ (Davis \& Blomstrom, 1975). CSR includes consideration of such issues as workplace and employee issues, human rights, including occupational health and safety, organizational governance, environmental aspects, community involvement, and social development.

Strategic CSR is about deciding the extent to which an organization should be involved in a corporate social agenda-considering what social issues to focus on and to what extent. Strategy is always about choice ${ }^{3}$ (Porter \& Kramer, 2006). Baron (2001) points out that CSR is what an organization does when it provides services along with its business and marketing strategy that has the potential to make the greatest social impact and reap the greatest business strategy ${ }^{[4]}$. CSR strategy determines how socially responsible behavior is exercised both outside and within the organization. Organizations should seek social/environmental strategies for which they own part of the solution.

A bank's CSR activities might be strategic if it uses some of its CSR budget to help educate young adults in 'financial literacy ${ }^{\text {[5] }}$. Because adults who are financially literate will usually go into unplanned debt less frequently and will realize their need for a range of financial products, many of which will be provided by the bank. So by supporting initiatives to increase financial literacy, the bank might be indirectly reducing bad debts and also increasing demand for its own products, gaining popularity and a competitive edge in the market.

Hillman and Keim (2001) state that the rationale for CSR is based on two propositions (cited in Armstrong, 2009). First, there is a moral obligation for businesses firms to do what is right without considering 
how such decisions affect firm performance and second, is that the firms can achieve a competitive advantage by trying CSR activities to primary stakeholders. CSR is about building a sustainable business which needs healthy economies, markets and communities. Globalization, international legal instruments and guidelines, changing public expectations of business, and business brand are some of the reasons organizations have begun to embrace CSR.

\subsection{Importance and Status of CSR in India}

CSR is recognized as a critical function contributing to accelerate the process of development of a nation. In India CSR is known from ancient time as social duty or charity, which through different ages is changing its nature in broader aspect. India being the second most populous country in the world, and home to the largest number of people in need of basic amenities, calls for more intensive efforts as part of such initiatives in the healthcare space of the nation.

In India, the concept of CSR is governed by clause 135 of the Companies Act, $2013^{6}$, which was passed by both Houses of the Parliament, and had received the assent of the President of India on 29 August 2013. It has many merits for one thing; it simplifies many issues and aims at greater transparency and ease of doing business in India. It has also introduced class action lawsuits, which will protect small holders, a remarkable move. The CSR provisions within the Act is applicable to companies with an annual turnover of 1,000 crore INR and more, or a net worth of 500 crore INR and more, or a net profit of five crore INR and more. The Act encourages companies to spend at least $2 \%$ of their average net profit in the previous three years on CSR activities. The Act lists out a set of activities eligible under CSR. Companies may implement these activities taking into account the local conditions after seeking board approval. The activities include promotion of education, eradication of extreme hunger and poverty, gender equity and women empowerment, environmental sustainability, employment enhancing vocational skills, combating HIV-AIDS malaria and other diseases.

The evolution of CSR in India can be divided into four phases ${ }^{7}$ (Fakay \& Buragohain, 2015):

CSR motivated by charity and philanthropy: It was characterized by the inclination of industrial families of the 19th century such as Tata, Godrej, Modi, Birla, and Singhania towards economic as well as social considerations.

CSR for India's social development: The second phase started with the independence movement where the industrialists were influenced by Mahatma Gandhi for socio-economic development of the nation. During this phase schools, colleges, training centers etc., were set up by various companies.

CSR under the paradigm of the mixed economy: the labor and environment laws were introduced in an independent India. The CSR activities were mainly taken by the Public Sector Undertakings (PSUs).

CSR at the interface between philanthropic and business approaches: the fourth phase started from1980 till the present. Indian started abandoning their traditional engagement with CSR and integrated it into a sustainable business strategy.

CSR in India has become an integral part of the corporate strategy. Companies have CSR teams that devise specific policies, strategies and goals for their CSR programs and set budget to support them. This contribution will be helpful to the organizations to enhance their brand awareness and reputation in the market. The society development should be treated as an integral part of the organization's strategy.

A few hindering factors of CSR are ambiguous policies, bureaucracy, poor monitoring, tax systems, and inadequate infrastructure ${ }^{8}$ (Centre for Social Markets, 2001). However it is believed that business organizations must play a wider role in the society apart from providing quality products at reasonable rates, making their operations environmentally sound, adhering to high labor standards, and reducing human rights abuses at the work place ${ }^{9}$ (Mishra and Suar, 2010). Consequently, Indian companies have started changing their outlook towards CSR by looking beyond passive philanthropy. Companies are considering CSR for improved brand image and stronger ties with the local community ${ }^{10}$ (Khan, S., 2014). CSR strategies promote the corporate sustainable development as well as society as at large. Therefore community development is a responsibility of the government, non-governmental organizations and business organizations as well.

Corporate Social Responsibility has been widely researched by researchers and theorists. The review of literature conducted sheds light on the nature and practice of CSR in various organizations and trends observed.

Sen and Bhattacharya ${ }^{11}$ (2001) examined how and for whom specific CSR initiatives work. The findings implicate that both company-specific factors, such as the CSR issues a company chooses to focus on and the quality of its products, and individual-specific factors, such as consumers' personal support for the CSR issues and their general beliefs about CSR, are key moderators of consumers' responses to CSR. The results also highlight the mediating role of consumers' perceptions of congruence between their own characters and that of the company in their reactions to its CSR initiatives. 
It is believed that the U.K companies are becoming ethical in the content of social responsibility because companies have to disclose their CSR with a view of public benefits and government request. Further, they have to issue this information to the stakeholders ${ }^{12}$ (Idowu and Loanna, 2007).

Holcomb, Upchurch \& Okumus ${ }^{13}$ (2007) identified and described social responsibility (SR) patterns in web sites, annual reports and corporate social responsibility (CSR) reports for the top ten hotel companies as listed in Hotels magazine. The findings reveal that 80 percent of the hotel companies analyzed reported socially responsible activities relating to some form of charitable donations. A diversity policy was reported by 60 percent of the hotel companies, while 40 percent provided some mention of SR in their vision or mission statements. Some companies were highly focused on providing a balanced approach to SR while other hotel companies were less focused in their efforts.

Another study (Mishra and Suar, 2010) examined whether corporate social responsibility (CSR) towards primary stakeholders influences the financial and the non-financial performance (NFP) of Indian firms. Data on CSR and NFP was collected from 150 senior-level Indian managers including CEOs through questionnaire survey. Controlling confounding effects of stock-listing, ownership, and firm size, a favorable perception of managers towards CSR is found to be associated with increase in FP and NFP of firms. Such findings hold well when CSR is assessed for the six stakeholder groups in aggregate and for each stakeholder group in segregate. Findings suggest that responsible business practices towards primary stakeholders can be profitable and beneficial to Indian firms.

In a study by Kumar (2013) CSR activities carried out by Indian private (RIL) and public sector companies (ONGC) and the Indian government policies and programmes of CSR were examined ${ }^{14}$. The data revealed that though the Indian public and private firms are making efforts in the CSR areas but still there is a requirement of more emphasis on CSR.

Singh and Singh (2015) analyzed the corporate social responsibility (CSR) activities carried out by public and private sector banks in India ${ }^{15}$. The analysis revealed that the work of CSR done by the Indian banking industry is a good initiative but there is a still room for development in this area. Some banks are lagging in the regulatory norms of CSR. It seems that banks are giving more emphasis on the social issues and financial issues to fulfill their social responsibility but environmental issues are touched little. Moreover, the public sector banks has overall higher spending than the private sector banks.

From the above literature it is evident that there is now a growing body of research that sheds important light on the growing importance of CSR in the organizations. India is a developing economy, here Corporate Social Responsibility (CSR) plays important role in organizations. In Indian industry one can easily notice a paradigm shift from corporate philanthropist to being socially responsible. The importance of CSR is increasing in Indian corporate scenario because organizations have realized that the ultimate goal is not profit making, beside this trust building is viable and assert able with societal relationship. The concept of CSR is based on the notion that the success of an organization and the welfare of the society are interdependent and both function inter-connectedly. The basic idea is that an organization cannot be successful if the society in which it operates functions ineffectively. CSR builds on the view that the organization and the society in which it functions are linked in that the changes in one affect and influences the other. If a society or community in which an organization functions is failing in terms of its environmental conditions, land degradation, poor health of the inhabitants and lack of literacy the chances of successful functioning of the organization is non-existent, if not bleak. Likewise, the success rate of a community is negligible if the organization that operates therein does not provide the services required by its inhabitants. Basing on this, the present study aims to understand and explore the types of CSR activities organizations engage in and how have these organizations attempted to make their mark as socially responsible members of the community.

\subsection{Objective}

- To analyze the Corporate Social Responsibility (CSR) activities carried out by an Indian public (Oriental Insurance Company Ltd.) and private sector (Reliance Life Insurance Company Ltd.) organization.

\section{Method}

The Case Study method was employed as a method of collecting data. A case study is a description or history of an event or a sequence of events in a real life setting. Case studies are used extensively in the HRM research as a means of collecting empirical evidence in the real life context. Information is gathered about an event or a set of events that establishes what has happened, how it happened and why it happened. They usually take the form of narrative that illuminates a decision or a set of decisions, why they were taken, how they were implemented and with what result. The methodology within the case study approach involves the use of multiple sources of evidence (triangulation) as far as possible such as observations, interviews, documents and records.

Case studies are useful ways of collecting information about the reality of organizations but there is a danger of the studies not being generalizable and not being able to contribute to greater knowledge or 
understanding. Case study requires the investigator to take an unbiased view and requires a lot of skill and persistence in gaining support, ensuring and revealing information is obtained and presented in a convincing manner from which valid and interesting conclusions can be drawn.

\subsection{Procedure}

The study was conducted on two insurance organizations, the Oriental Insurance Company Ltd and Reliance Life Insurance Company Ltd. Prior to the conduction of the interview, researchers identified the public and private sector organizations and approached them. It was ensured that the organizations chosen for the purpose of the study belonged to the same level i.e. ensuring that both the organizations were established around the same time. While for Oriental Insurance Company Ltd primary data was collected, for Reliance Life Insurance Company Ltd. secondary data obtained through the organization's CSR reports, documents, records and website. The supervisor was approached and was communicated the general nature and purpose of the study. A proposal letter was presented and permission was sought through a representation. After being duly accepted the research proceeded. Before the data collection began a probe list was formed and an interview schedule was formulated that covered the domains the researchers wished to explore. The HR executive of the organization was identified and an appointment was sought. Once a particular date and time was fixed with the participant, the study was carried forward. Before the conduction, the participant was asked to sign the informed consent and was informed about the nature and purpose of the study. The participant was also presented with a demographic sheet and was asked to fill in the sheet. Permission to record the interview was sought. The participant was assured of the confidentiality of his/her responses, identity and results and was promised a quick and effective feedback. A semi-structured interview was conducted. The questions were later rephrased in a way that would best elicit the desired response from the participants.

Special attention and focus was paid on the formation of rapport with the participant, as the interview required the participant to disclose professional information. The purpose was to make the participant comfortable and to avoid any socially desirable or fake responses and achieve genuine results. It also aimed to reduce any sort of anxiety and apprehensions that he/she might be experiencing or having.

During the interview the process notes were taken and the non-verbal cues of the participant were observed and noted. The researcher attempted to remain as neutral and detached as possible at the same time being tolerant, sensitive and patient to provocative and unconventional opinions. A smooth transition was ensured between major topics. The researcher's attempt was not to lose control of the interview and control the course of the interview to avoid digression from the topic. Once the interview was over, the participants were once again promised of confidentiality and anonymity.

Secondary data sources were referred to gather data about Reliance Life Insurance Company Ltd. Later, the data obtained from the participant of the private insurance company and the data obtained from the secondary sources about the CSR activities were organized and analyzed. Thematic analysis was used which is a method for identifying, analyzing, and reporting patterns (themes) within data. A theme is described as that which captures something important about the data in relation to the research question, and represents some level of patterned response or meaning within the data $\operatorname{set}^{16}$ (Braun \& Clarke, 2006). It is a way through which the embedded ideas in the text, document or interviews surface and help us understand the essence data. The data obtained from both the organizations, Oriental Insurance Company Ltd. and Reliance Life Insurance Company Ltd were analyzed and have been represented in tabular form.

\section{Results}

Thematic analysis was used to analyse the primary and secondary data. The categories under which CSR activities are being done by Oriental Insurance Company Ltd. are given in Table 1.

Table 1. CSR Activities adopted by Oriental Insurance Company Ltd. (Public)

\begin{tabular}{|c|c|c|}
\hline Activities done by the organization & Codes & Categories \\
\hline Village development & Rural Development & \multirow[t]{2}{*}{ Community Development } \\
\hline Collaboration with HelpAge India & $\begin{array}{l}\text { Collaboration with NGO's for the } \\
\text { elderly and children education }\end{array}$ & \\
\hline Tree Plantation & \multirow[t]{2}{*}{ Greening Activities } & \multirow[t]{3}{*}{ Environment } \\
\hline Paper Saving and recycling & & \\
\hline $\begin{array}{l}\text { Collaboration with Government for the protection and } \\
\text { maintenance of Heritage Monuments }\end{array}$ & $\begin{array}{l}\text { Collaboration with government for } \\
\text { the protection of Monuments }\end{array}$ & \\
\hline $\begin{array}{l}\text { Paper Saving Drive and Paper Recycling within work } \\
\text { premises }\end{array}$ & Sustainable use of Paper & Workplace \\
\hline $\begin{array}{l}\text { Cancer Prevention and Awareness programs and } \\
\text { workshops with Cancer Patient Aid Association }\end{array}$ & Health awareness programs & \multirow[t]{3}{*}{ Health } \\
\hline Physical \& Veterinary camps & \multirow[t]{2}{*}{ Health care programs } & \\
\hline Health awareness & & \\
\hline
\end{tabular}


Corporate Social Responsibility in India: A Case Study of Public and Private Sector

\begin{tabular}{|l|l|l|}
\hline Health check-ups & & \\
\cline { 1 - 1 } Blood donations camps & \multirow{2}{*}{ Education for the underprivileged } & Education \\
\cline { 1 - 1 } Education for orphans & & \\
\hline Educational aids for underprivileged children & & \\
\hline
\end{tabular}

The categories under which CSR activities are being done by Reliance Life Insurance Company Ltd. are given in Table 2.

Table 2. CSR Activities adopted by Reliance Life Insurance Company Ltd. (Private)

\begin{tabular}{|c|c|c|}
\hline $\begin{array}{l}\text { Activities done by the organization } \\
\end{array}$ & Codes & Categories \\
\hline Rural transformation & Rural Development & \multirow[t]{3}{*}{ Community } \\
\hline Promoting gender equality & Gender Issues & \\
\hline Monument and heritage protection & Heritage Conservations & \\
\hline Educating farmers about water conservation & \multirow[t]{2}{*}{ Work empowerment } & \multirow[t]{3}{*}{ Empowerment } \\
\hline Educating farmers about water management & & \\
\hline $\begin{array}{l}\text { Using technology towards delivering need based information } \\
\text { for improving quality for improving quality of life. }\end{array}$ & Increasing quality of life & \\
\hline Tree plantation & \multirow[t]{2}{*}{ Greening Activities } & \multirow[t]{3}{*}{ Environment } \\
\hline conservation of flora and fauna & & \\
\hline Maintaining quality of air, soil and water. & $\begin{array}{l}\text { Environment and Climate } \\
\text { Protection }\end{array}$ & \\
\hline Ethical treatment and fair business practices that promote & Employee Welfare & Marketplace \\
\hline Awareness programmes on health and hygiene & Health awareness & \multirow[t]{5}{*}{ Health } \\
\hline $\begin{array}{l}\text { Recognizing the rural-urban divide with regard to health care } \\
\text { facilities }\end{array}$ & \multirow[t]{3}{*}{ Health care facilities } & \\
\hline Execution of medical programmes in hospitals & & \\
\hline Vaccination programmes in inaccessible areas & & \\
\hline Improve food security and enhance nutrition & Nutrition & \\
\hline Monetary assistance to schools & \multirow[t]{2}{*}{ Infrastructure Development } & \multirow[t]{4}{*}{ Education } \\
\hline Infrastructure Development & & \\
\hline $\begin{array}{l}\text { Collaboration with government and quasi-government } \\
\text { agencies to promote reforms in education such as exposure to } \\
\text { technology }\end{array}$ & Educational Reforms & \\
\hline Involvement in Project Jagruti. & $\begin{array}{l}\text { Independent Educational } \\
\text { Projects }\end{array}$ & \\
\hline
\end{tabular}

\section{Discussion}

A corporate takes birth and grows in response to the needs and labors of various stakeholdersentrepreneurs, managers, workers, local community, larger society, buyers, suppliers and the state. The relationship between that of the community and organization can be understood as involving a reciprocal relationship wherein the activities of the organization influences the community and vice versa. It is in the best interest, therefore of both the community and organization to act in ways that promote each other's development and promotion. Corporate Social Responsibility is one such way that ensures development and promotion of the best interest of both the parties. Therefore, in order to explore the concept further the purpose of the present study was to study and understand the corporate social responsibility (CSR) strategy in an Indian public and private sector organization and to analyze the CSR strategies carried by the organization in these two sectors.

The organizations chosen for the purpose of the study was the public sector, Oriental Insurance Company Ltd (OICL) and the private sector, Reliance Life Insurance Company Ltd. (RLIC). The researcher gathered primary data by visiting the Public sector organization and secondary data was used to explore the CSR activities and strategies of the private sector organization. The Case Study method was employed as a method of collecting data. The data obtained from both the organizations, Oriental Insurance Company Ltd. and Reliance Insurance Ltd were analyzed using thematic analysis.

\subsection{CSR activities of Oriental Insurance Company Ltd.}

The OICL was established in 1947 and is a public sector organization. The headquarters of the company is located in Delhi and has 30 regional offices. The goal of the company is to serve the clients and the corporate vision of the organization is to be the "the best and most preferred insurer in the markets" in which they operate. The participant stated that the undertaking CSR activities was delineating its responsibility as a corporate citizen and laying down the guidelines and mechanism for undertaking socially useful programmes. Corporate Citizenship is defined as the extent to which businesses are socially responsible for meeting responsibilities placed on them by shareholders. The CSR activities of OICL began in 2010 and places great importance on meeting these responsibilities. The vision of CSR for the OICL is to participant in programmes that benefit the society at large and also those who need special assistance. Their objective was to operate its 
business in a manner that is economically, sustainably and environmentally sustainable manner and enhance the quality of life of the community and people for whom the CSR programs are designed.

The interview with the branch head of OICL revealed that the organization was involved in a number of CSR activities and followed a systematic procedure of planning, budget allocation, implementation, evaluation and feedback. The interview revealed that the company viewed the CSR activities and strategies as a means to reach out to people with the intention of improving their welfare and wellbeing. They had an established committee that reviewed various proposals for CSR activities before they were actually implemented. As table 1 shows the organization was involved in community activities such as village development and collaboration with NGO's for cancer prevention, old age and children's education.

The participant stated that they organized several workshops and outdoor activities. A variety of activities in the community domain were undertaken by the organization. On its founder's day an educational trip was organized for orphan children where they were educated about India's history and heritage. In addition they also provide infrastructure facilities to old age homes and work with NGO's like HelpAge India and Janseva Foundation.

The organization is also actively involved in activities that pertain to the environment such as regular plantation drive and ensuring the use of recycling products and minimizing paper usage. Paper saving drive and paper recycling was also practiced within the work premises indicating that organization's thrust areas of sustainable environment development was not only practiced outside but also within the organization at the workplace.

The organization participates extensively in the dimension of health by creating awareness and promoting cancer prevention programmes by organizing independent workshops as well as by working in collaboration with several non-profit organizations such as Cancer Patient Aid Association, . Physical \& Veterinary camps are held in rural areas, Health awareness, check-up and blood donations camps held at 68 locations across the Country on a single day i.e. 28, January every year. In addition to various children welfare activities such as organizing educational trips and hygiene and health awareness programmes, the organization has tie-ups with government programmes for the protection of monuments and heritage buildings. All these activities reflect the wide areas and domains the organization attempts to cover.

When the participant was asked as to why she thought organizations engaged in CSR activities, the participant promptly replied saying that engaging in CSR activities came not only with the added advantage of helping people but also "then by doing so (CSR), we are increasing our repertoire of activities which is helping us gain a positive image. It has benefits for all. But yes, the aim is to help people." A global survey of 1,122 corporate executives proposes that CEOs believed that "businesses benefit from CSR because it increases attractiveness to potential and existing employees" ${ }^{\prime 17}$ (Economist. 2008: 13).Perhaps the challenge experienced by the organization is in terms of the allocation of budget which determines how to operate and carry out CSR activities.

Although they had their structured guidelines and a subcommittee a challenge that the researchers believe the organization faces in addition to the issue of allocation of budget is the Lack of Consensus on Implementing CSR Issues as all the decision are taken by the subcommittee which leads to a lack of consensus amongst local agencies regarding CSR projects. This lack of consensus often results in duplication of activities by corporate houses in areas of their intervention. This factor limits company's abilities to undertake impact assessment of their initiatives from time to time.

\subsection{Reliance Life Insurance Company Ltd.}

The second organization chosen was the Reliance Life Insurance Company Ltd. is a part if the Reliance Capital of the Reliance Group that was established in 1966. The vision of RIL is "to be a company people are proud of, trust in and grow with; providing financial independence" to every life they touch. Their philosophy is to touch the lives of people and "do good" which is their aim and intent. The CSR activities undertaken by the organization began in 2008 and the RLIC just like OICL engages in a plethora of CSR activities aimed at promoting good will and welfare of the community and society ${ }^{18}$.

The RLIC is extensively involved in the community development and upliftment programmes ranging from rural transformation, promoting gender equality, monument and heritage protection programmes. The aim of community programmes is to create sustainable livelihood solutions, addressing poverty, hunger and malnutrition. The organization has targeted extensively itself towards rural development and empowerment by educating farmers about water conservation and management and using technology towards delivering need based information for improving quality for improving quality of life. The company also has programmes that aim to improve food security and enhance nutrition. Like OICL, RLIC also preserves the rich heritage but not in collaboration with any government programmes. The organization undertakes heritage preservation activities on its own ${ }^{19}$. 
With regard to environment, the company has undertaken a number of plantation and greening activities and remains steady in its vision of creating a sustainable environment. As Taylor (2015) state companies also demonstrate their corporate social responsibility by treating employees fairly and ethically ${ }^{20}$. The RLIC too demonstrates its CSR by claiming to practice workplace ethics and ensuring fair treatment and safety of their employees. Under the health domain the organization recognizes the rural-urban differences that exist in India in terms of health care facilities. While in the urban setup the organization has collaborated with the broader Reliance Industries in contributing and execution of medical programmes in hospitals in the urban areas, the organization conducts awareness programmes on health care facilities and vaccination campaigns in the inaccessible rural areas. With regard to education the organization provides monetary assistance to schools contributes to infrastructure development. A noteworthy mention is the organizations contribution to the organizations' self-initiated project for dyslexic students called 'Project Jagruti'. The project initiated in 201112 aims to tackle dyslexia and also aims to break the social dogma of the mentally underprivileged children. Volunteers from the organization help in making the programme successful and create awareness and opportunities for these children.

\subsection{Comparison of Oriental Insurance Company Ltd. \& Reliance Life Insurance Company Ltd.}

While both the organizations are engaged in CSR activities that cover a variety of domains and areas, it is observed that the CSR activities in the private sector company (RLIC) were more varied and diverse as compared to the public sector company (OICL). OICL, although had numerous undertaking and CSR proposals, it appeared that the tasks undertaken by OICL were less as compared to RLIC. In addition, another difference that emerged was that while RLIC had several programmes that were self-initiated, OICL had very few programmes that were self-initiated and these activities and programs did not appear to be on a large scale as compared to the programmes of RLIC. For instance, while RLIC initiated Project Jagruti that aims to help dyslexic students with RLIC volunteers and well-developed programs, OICL had self-initiated programs that are basically short term, one-day programs such as organizing an educational trip for orphans which includes lectures, workshops and refreshments for children and volunteers. Another point of difference that was observed was that the programs undertaken by RLIC seemed to be more structure ${ }^{21}$ and definite while it did not appear to be so in the case of OICL, although OICL had a systematic procedure laid that was involved in the planning and execution of CSR proposals and programs, the programs under OICL did not appear to have as much structure when they were compared with the programs undertaken by RLIC.

\section{Conclusion}

India is a developing economy where Corporate Social Responsibility (CSR) plays important role in organizations. Overall, there appears to be a difference in the CSR strategies adopted by private and public sector organizations. The study has the potential to contribute to the understanding of how CSR activities are carried out and the nature of these activities in different organizations. The more the concepts of CSR are fostered and integrated into the business process, the easier it will be to benefit from alternative thinking. The study also highlights the differences that might exist in different sectors. There were several limitations inherent in the study, such as the use of primary data sources for one organization and the secondary data sources for another organization which did not provide a complete and fulfilling understanding of the CSR endeavors in both the organizations. The use of a single interview of only the HR/ branch head did not yield as much detail regarding the CSR activities, and other employees of the organization could also be interviewed in order to gain a more comprehensive understanding. In addition a cost analysis and allocation of funds could be analyzed. Future studies can take into account the above mentioned consideration that would provide a more holistic understanding of this influential yet unexplored area. There exists a paucity of research in the Indian context regarding the CSR activities undertaken by different organizations. Future research can use a more holistic manner of analyzing the various CSR activities such as using primary and secondary data together in addition to interviews with the HR's and the employees of the companies. Future studies could also undertake an analysis of the budgets allotted by organizations in order to further aid in assessing the varied activities undertaken by the organization.

[1] M. Armstrong, Armstrong's handbook of human resource management practices (11 ${ }^{\text {th }}$ Ed.). (United Kingdom, London: Kogan Page, 2009)

[2] K. Davis \&R.L. Blomstrom, Business and society: Environment and responsibility. (New York: McGraw-Hill, 1975).

[3] Porter, M. E., \& Kramer, M. (2006). Strategy and society: the link between competitive advantage and corporate social responsibility. Harvard Business Review, 78-92.

[4] Baron, David. (2001). Private politics, corporate social responsibility and integrated strategy. Journal of Economics and Management Strategy, 10, 7-45.

[5] ACCA Global. (2016). CSR strategy and strategic CSR. Retrieved 9 April 2016, from http://www.accaglobal.com/za/en/student/exam-support-resources/professional-exams-study-resources/p1/technicalarticles/csr.html 
[6] Ministry of Corporate Affairs. (2013). The Companies Act, 2013.

[7] Fakay, Y., \& Buragohain, B. (2015). Corporate social responsibility: a review of literature. Indian Journal of Research, 4(2). 197200 .

[8] Centre for Social Markets. (2001). Corporate Social Responsibility: perceptions of Indian business. London/Calcutta.

[9] Mishra, S. \& Suar, D. (2010). Does corporate social responsibility influence firm performance of Indian companies? Journal of Business Ethics, 95, 571-601.

[10] Khan, S. (2014). Corporate Social Responsibility in Multinational Companies in Emerging Economies. Business Dimensions, 1(1), 23-37.

[11] Sen, S. \& Bhattacharya, C.B. (2001). Doing good always lead to doing better? Consumer reactions to corporate social responsibility. Journal of Marketing Research, 38(2), 225-243.

[12] Idowu, S. \& Loanna, P. (2007). Are corporate social responsibility matters based on good intentions or false pretenses? A critical study of CSR report by UK companies. Corporate Governance Journal. 7(2), 136-147.

[13] Holcomb, J.L., Upchurch, R.S., \& Okumus, F. (2007). Corporate social responsibility: what are top hotel companies reporting? International Journal of Contemporary Hospitality Management, 19(6), $461-475$

[14] Kumar, M.R. (2013). Corporate social responsibility (Analysis of Select Indian Private and Public sector companies). International Journal of Innovative Research in Science \& Engineering. Retrieved 14 June, 2017 from http://ijirse.in/docs/Apr14/IJIRSE140411.pdf.

[15] Singh, I.P., \& Singh, T.I.D. (2015). Comparative analysis on corporate social responsibility in public and private sector banks of India. International Journal of Research in Management, Economics \& Commerce, 5(3), 128-138.

[16] Braun, V. \& Clarke, V. (2006). Using thematic analysis in psychology. Qualitative Research in Psychology, 3 (2), $77-101$.

[17] Economist. (2008). Just good business. Special report on CSR. January, $19^{\text {th }}$.

[18] Reliance Broadcast Network. (2016). Reliancebroadcast.com. Retrieved 9 April 2016, from http://www.reliancebroadcast.com/corporate_sr/corporate_sr.html

[19] Social Responsibility \& Community Development :: Reliance Industries Limited. (2016). Retrieved 9 April 2016, from http://116.50.66.238/html/aboutus/social_resp_comm_dev.html.

[20] Taylor, N.F. (2015). What is Corporate Social Responsibility. Business News Daily. Retrieved 9 April 2016, from http://www.businessnewsdaily.com/4679-corporate-social-responsibility.html.

[21] Reliance Life Insurance Company Limited. (2015). CSR Policy. Retrieved on $12 \quad$ May, 2017 from http://www.reliancenipponlife.com/download_forms/csr\%20policy\%20-\%20rlic.pdf 